Journal of Advanced Research in Fluid Mechanics and Thermal Sciences

Journal homepage: www.akademiabaru.com/arfmts.html ISSN: $2289-7879$

\title{
Improvement of Photovoltaic Module Efficiency using Spiral Absorber and Water
}

\author{
Nur Farhana Mohd Razali ${ }^{1}$, Ahmad Fudholi ${ }^{1,}{ }^{*}$, Mohd Hafidz Ruslan ${ }^{1}$, Kamaruzzaman Sopian $^{1}$ \\ 1 Solar Energy Research Institute, Universiti Kebangsaan Malaysia, 43600 Bangi Selangor, Malaysia
}

\section{ARTICLE INFO
ABSTRACT}

Article history:

Received 23 April 2020

Received in revised form 31 May 2020

Accepted 3 June 2020

Available online 5 July 2020

Keywords:

Cooling system; power; fill factor; I-V

curve; $\mathrm{P}-\mathrm{V}$ curve

\begin{abstract}
This study presents an experimental investigation intended to improve the power output of a photovoltaic (PV) module using a spiral absorber and water as coolants. This cooling system, known as a photovoltaic thermal (PVT) water collector, can generate thermal (hot water) and electrical energy simultaneously. Results show that by adding coolants, the maximum power and open circuit voltages are improved; hence, the output power also increases. In addition, the power generated increases with the addition of solar radiation, and PV module efficiency becomes slightly higher than that of the PV module without cooling. The electrical characteristics of the PV module are represented by plotted current-voltage and power-voltage curves.
\end{abstract}

Copyright @ 2020 PENERBIT AKADEMIA BARU - All rights reserved

\section{Introduction}

The human population of the planet will only continue to increase. Economic development and the country's rapidly growing energy needs for maintaining human life are increasing sharply. However, the burning of fossil fuels is not the only problem facing humankind. Another serious issue is the lack of sources of fossil fuels, such as petroleum and natural gas. The diminution of fossil fuels is the most important global issue, especially with western countries prioritising the use of energy from fossil fuels. The demand for fossil fuels, especially petroleum, has been increasing worldwide, and the supply of petroleum is believed to have already reached its climax, as evidenced by the increasing price of crude oil. The vast demand for energy will eventually lead to the depletion of fossil fuel supply, and efficient solutions need to be created to deal with this inevitable problem. To handle this serious issue, western countries have been creating substantial progress in the issuance of national development policies to address high energy demand and low fuel source supply. Among the policies implemented, the most promising solution is to search for new energy sources [1-3].

\footnotetext{
* Corresponding author.

E-mail address: a.fudholi@ukm.edu.my
} 
Thermal and electrical energy can be produced from solar energy. Heat energy can also be divided into two media: water and air. Both absorb heat from thermal energy for use in different fields. In terms of thermal energy, the warm water generated from solar energy can be used in hotels or inns, homes, hospitals and laundries. Hotels and residential houses usually require warm water for bathing and drinking. Hospitals also need an ample amount of hot water for washing medical devices. Solar energy received on the Earth's surface can be divided into two types: photons for generating electricity and thermal energy. Apart from the energy use of petroleum for vehicles, electrical energy is essential in our lives. Nearly all daily human activities require electricity. Heat energy can also be used for air heating during winter, production of hot water for bathing and washing, cooking and drying, among others [4-6].

The latest solar technology integrates solar thermal with photovoltaic (PV) technology and is called thermal photovoltaic technology (PV/T). This technology converts solar energy into thermal energy. Solar energy efficiency through $\mathrm{PV} / \mathrm{T}$ is considerably higher than that of $\mathrm{PV}$ and solar collectors on the same surface area of the collector. PV cell efficiency decreases if the operating temperature of the system is high. Therefore, solar collectors attached to PV cells cool the cells and increase the overall efficiency of the PV/T system. Space-saving PV/T construction is suitable for domestic consumption, and long-term cost savings are the focus of current $P V / T$ research in renewable energy technology. PV/T classification can be divided according to heat transfer medium, fluid flow mode, system installation and configuration. The air-based PV/T system is cheap and easy to develop, but the system has low efficiency when the ambient temperature rises above $20{ }^{\circ} \mathrm{C}$. Therefore, water cooling is suitable for ensuring that the PV/T system works effectively. During its emergence, the PV/T system mostly used air as a coolant because of easy installation and low cost. Since then, various improvements in system design have been proposed to increase the efficiency of heat transfer and absorption of solar radiation of the system. These improvements include additional fins on the fluid route, thermal absorption design and multiple pathways on the coolant [7-16]. Kern and Russell [17] proposed the concept of PVT collectors using water or air as a heat removal fluid. Bahaidarah et al., [18] performed an evaluation of a PV module via back surface water cooling and concluded that PV panel efficiency increased by $9 \%$ under water active cooling. Raghuraman [19] introduced several methods for predicting the efficiency achieved by an air and water PV/T collector flat plate. Chow et al., [20] investigated energy and exergy analyses of a PV/T water-based collector system with and without glass cover.

Many experiment studies focused on the size, arrangement and type of fluid used for cooling in PVT collectors. The main objective of the current work is to investigate the efficiency of PV module with and without cooling (spiral absorber and water).

\section{Materials and Methods}

Experiments were performed in the Solar Lab at Level 3 of the Physics Building, Universiti Kebangsaan Malaysia. The radiation was sourced from a simulation lamp, and the experiment was set up with different radiation intensities $\left(500,700\right.$ and $\left.900 \mathrm{~W} / \mathrm{m}^{2}\right)$. Figure 1 shows the setup of the $\mathrm{PV} / \mathrm{T}$ collector during an indoor experiment under the solar simulator. In this experiment, a standard PV panel with $80 \mathrm{~W}$ rated power was used. The surface area of this PV panel was $1.2 \mathrm{~m} \times 0.5 \mathrm{~m}$, and its width was $0.0045 \mathrm{~mm}$. The ambient temperature and other temperatures (inlet, outlet and PV) were measured using a K-type thermocouple and were obtained from several places around the PV/T water collector. The radiation from the simulation lamp was measured by a pyranometer. Data from the thermocouple and pyranometer were recorded in a computer linked by the data acquisition system ADAM, which was selected for its capability to record data of input voltage, current and 
temperature simultaneously. The change in temperature during the experiment could be tracked and recorded in a short step time $(1 \mathrm{~min})$. The total incident radiation on the system was measured by a pyranometer. A flow meter (1-4 G/M) was mounted at the opening of the fluid inlet to control the mass flow rate.

Spiral collecting spider tanks were selected in this study, according to Ibrahim et al., [21], Aisyah et al., [22] and Fudholi et al., [23]. The improvement of the looser form of this study was in the diameter of the absorber, which was raised to increase the touch surface area between the PV module and the absorber. The material used to build this absorber was a rust-proof patient. The conductivity of the terminus was $16.3-20.0 \mathrm{~W} / \mathrm{mK}$. This material was selected because it is cheaper than copper and has high calorific resistance. Figure 2 shows the spiral stainless absorber. The width of the absorber is $1.9 \mathrm{~cm} \times 1.9 \mathrm{~cm}$, and the thickness is $1 \mathrm{~mm}$.

The experiment was conducted in an indoor testing facility using a solar simulator. The simulator consisted of 40 halogen lamps, and the intensity of solar radiation was controlled by a variable voltage controller. The PV/T water collector was exposed to solar radiation of $900 \mathrm{~W} / \mathrm{m}^{2}$ for $40 \mathrm{~min}$ before data collection to ensure an equilibrium state of radiation. The change in voltage was recorded using an electric load under different mass flow rates. The mass flow rate of water ranged from 0.01 $\mathrm{kg} / \mathrm{s}$ to $0.0255 \mathrm{~kg} / \mathrm{s}$. The temperature of the system was recorded from the thermocouple stored in ADAM every minute and was subsequently used to calculate the electrical and thermal efficiency of the collector. The water was circulated around the system using a pump and heat exchanger, which are used for cooling fluids in closed-loop systems.

Electrical data collection for current, voltage, short circuit current $\left(I_{s c}\right)$ and open circuit voltage $\left(V_{\text {oc }}\right)$ used the electronic load of an 8500 model from BK Precision. Data obtained were used to plot the I-V curve graph. Maximum power $\left(P_{m}\right)$ can be determined from the graph.

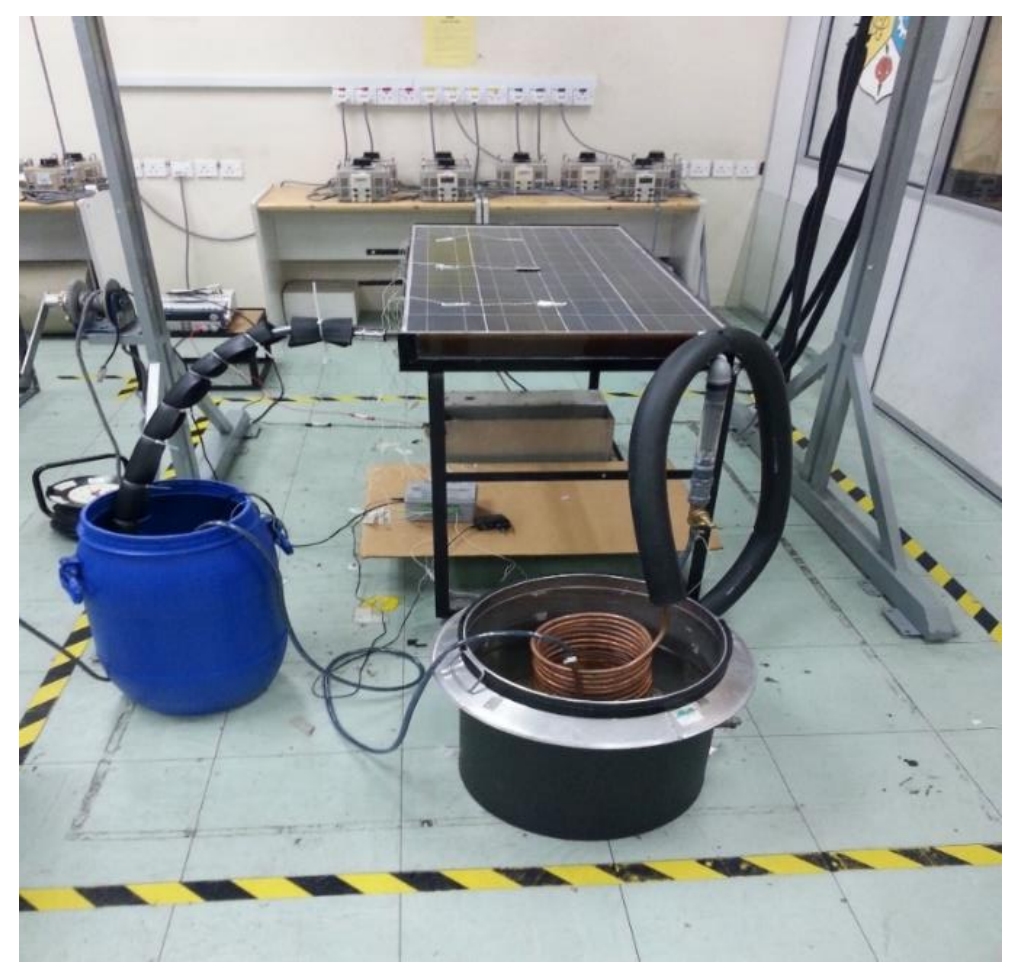

Fig. 1. PV/T water collector under a solar simulator 


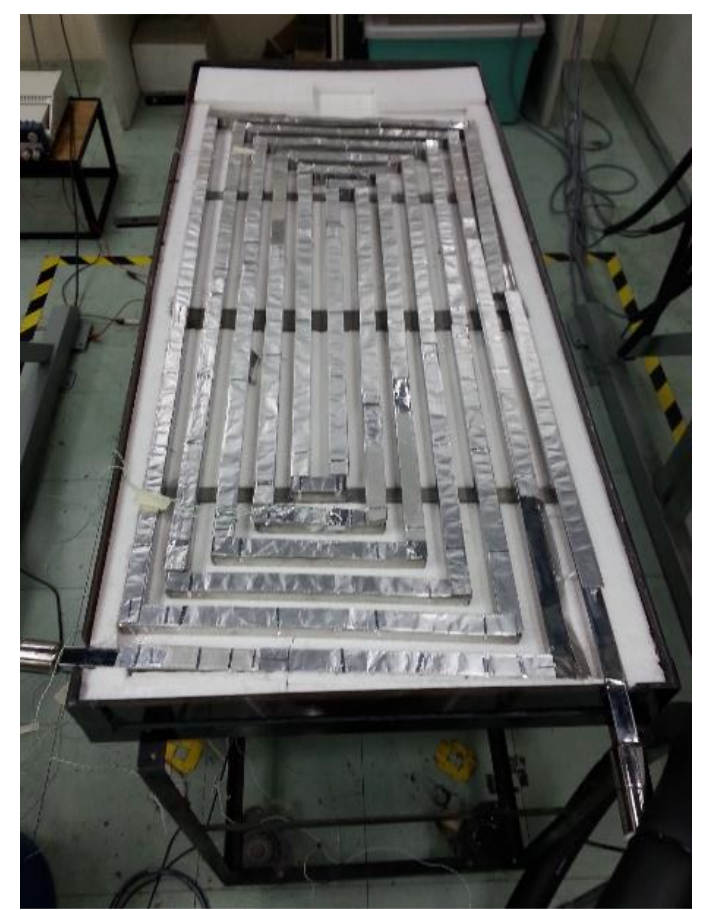

Fig. 2. Spiral absorber

The electrical efficiency of the PV module was measured by the maximum power ratio $\left(P_{m}\right)$ to the intended radiation.

$\eta_{p v}=\frac{P_{m}}{G A_{c}}$

where $A_{c}$ is the surface area of the collector, $G$ is the intensity of radiation, and $P_{m}$ is derived from the equation.

$P_{m}=V_{m} \times I_{m}$

The features of a PV module can be removed from the PV module output, which can be explained by the resulting I-V curve nature. The curve changed as a function of the PV temperature ( $\left.T_{p v}\right)$ and of the radiation intensity $(\mathrm{S})$ received by the module.

The fill factor (FF) of a PV module is a measure of the real I-V characteristic curve. It is defined as the $\mathrm{Pm}$ produced by the cell against the open circuit voltage product $\left(\mathrm{V}_{\text {oc }}\right)$ and the closed-circuit current $\left(I_{s c}\right)$. FF can be written as

$F F=\frac{P_{m}}{V_{o c} \times I_{s c}}$

\section{Results and Discussion}

The PV module without a collector needs to be studied first for obtaining reference data for the actual capabilities of the PV module used. The PV module was thus studied for exploring the PV/T water collector. The output power and PV temperature data were recorded to assess the efficiency of the PV module. Figure 3 shows the I-V curve and the power changes generated from the PV module without cooling. Results of these tests are summarized in Table 1. I sc changed from $0.868 \mathrm{~A}$ to $2.114 \mathrm{~A}$, and $\mathrm{V}_{\text {oc }}$ decreased from $16.44 \mathrm{~V}$ to $15.66 \mathrm{~V}$ when the intensity of radiation changed from 
$500 \mathrm{~W} / \mathrm{m}^{2}$ to $900 \mathrm{~W} / \mathrm{m}^{2}$ directly. The power increased from $9.562 \mathrm{~W}$ to $21.692 \mathrm{~W}$ when the intensity changed within the same range. The FF of the PV module ranged from 0.670 to 0.655 .

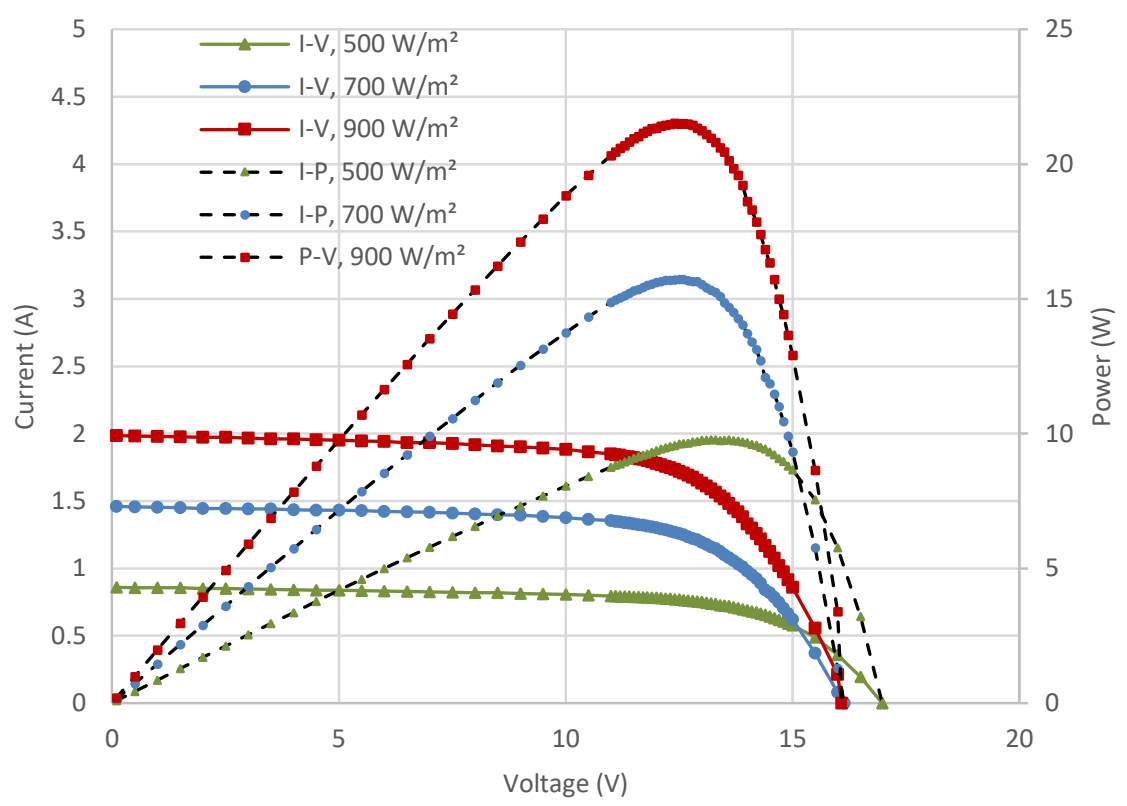

Fig. 3. Current (I) and power (P) over voltage (V) for the PV module without cooling under different radiation intensities

\section{Table 1}

Electrical characteristics of the PV module without cooling under the intensity of the simulator radiation

\begin{tabular}{llllll}
\hline $\mathrm{S}\left(\mathrm{W} / \mathrm{m}^{2}\right)$ & $\mathrm{I}_{\mathrm{sc}}(\mathrm{A})$ & $\mathrm{V}_{\mathrm{oc}}(\mathrm{V})$ & $\mathrm{P}_{\text {maks }}(\mathrm{W})$ & $\mathrm{FF}$ & $\eta_{e l}(\%)$ \\
\hline 500 & 0.868 & 16.44 & 9.562 & 0.670 & 3.08 \\
700 & 1.472 & 15.77 & 15.348 & 0.661 & 3.38 \\
900 & 2.114 & 15.66 & 21.692 & 0.655 & 3.69 \\
\hline
\end{tabular}

The efficiency obtained from this test was relatively low, ranging from $3.08 \%$ to $3.69 \%$. Consequently, the modules used in this PV/T water collector were identified to a have lower electrical performance $(12.5 \%)$ than the specs obtained from the suppliers. PV module testing under standard conditions of $1000 \mathrm{~W} / \mathrm{m}^{2}$ and $25{ }^{\circ} \mathrm{C}$ obtained an $I_{s c}$ of $5.15 \mathrm{~A}, V_{o c}$ of 21.6 and $\eta_{p v}$ of $12.5 \%$. The difference in $I_{s c}$ value was more pronounced than the $V_{o c}$ value compared with the tests conducted due to the long-term PV module quality factor. The performance of the PV module was important for comparison with that of the PV/T water collector. The PV/T collector was operated under the same test conditions to ensure that the electrical capabilities of the PV module were in line with the theory of $\mathrm{PV} / \mathrm{T}$ water collector construction.

This PV/T water collector was tested in the laboratory at the same temperature and humidity as that of the test of the PV module. The effect of thermal collectors on water on the $I_{s c}$ and $V_{o c}$ of PV modules was studied firstly. The PV/T water collector was placed under the intensity of the simulator radiation at 500,700 and $900 \mathrm{~W} / \mathrm{m}^{2}$ rays and mass flow rates of $0.012 \mathrm{~kg} / \mathrm{s}$ to $0.0255 \mathrm{~kg} / \mathrm{s}$. The inlet water flow temperature was set at $26^{\circ} \mathrm{C}$ by cooling the fluid in the cooling tank before entering the collector. $I_{s c}$ and $V_{o c}$ were recorded for each change in radiation intensity and mass flow rate. All 
recorded I-V values were then plotted in Figure 4 to 6 . Results of the study on intensity and fluid flow rates for the PV/T water collector are summarized in Table 2.

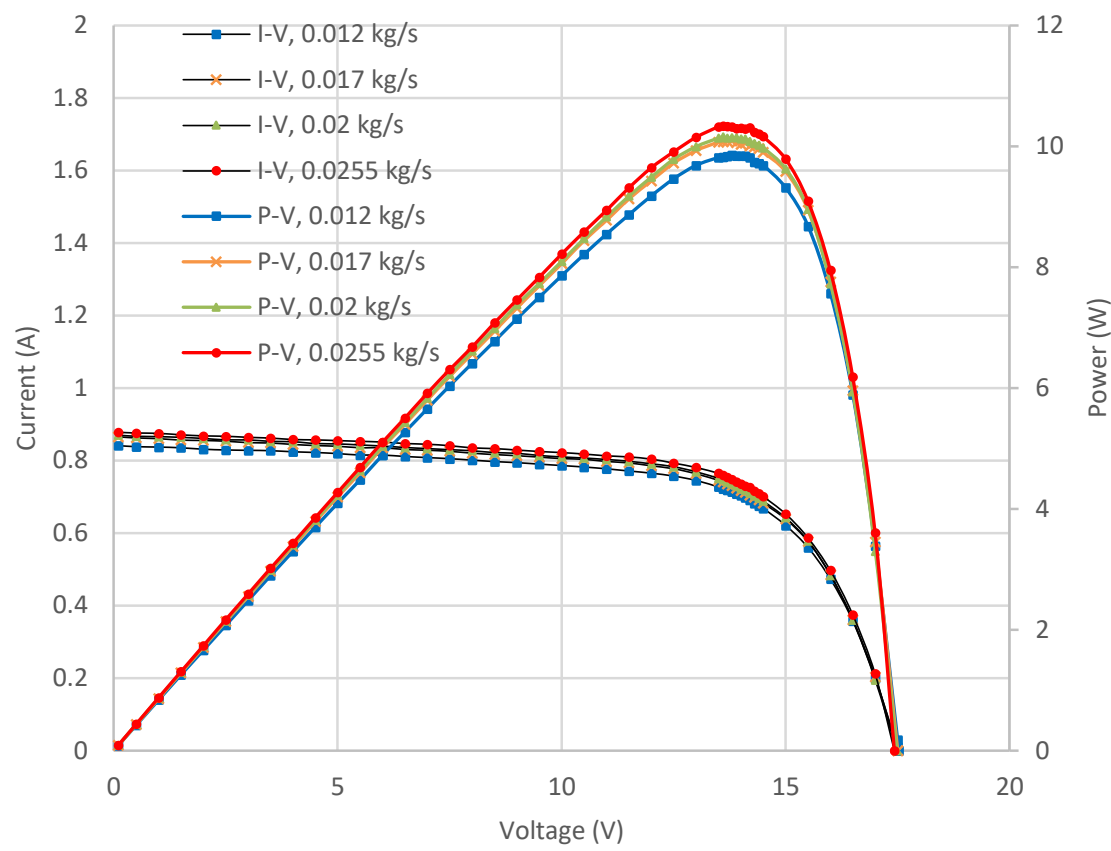

Fig. 4. Current (I) and power (P) over voltage (V) for the PV module with cooling at $500 \mathrm{~W} / \mathrm{m}^{2}$ intensity

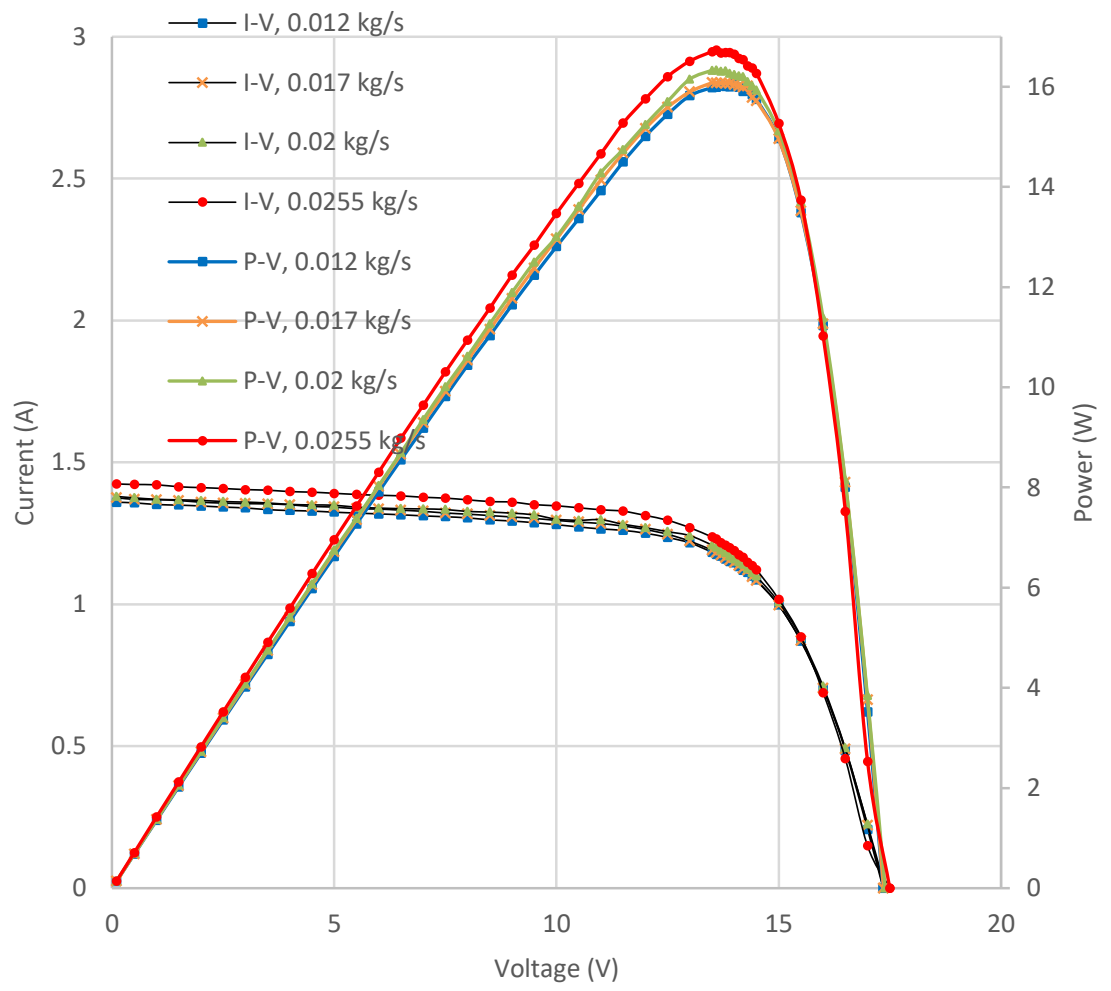

Fig. 5. Current (I) and power (P) over voltage (V) for the PV module with cooling at $700 \mathrm{~W} / \mathrm{m}^{2}$ intensity 


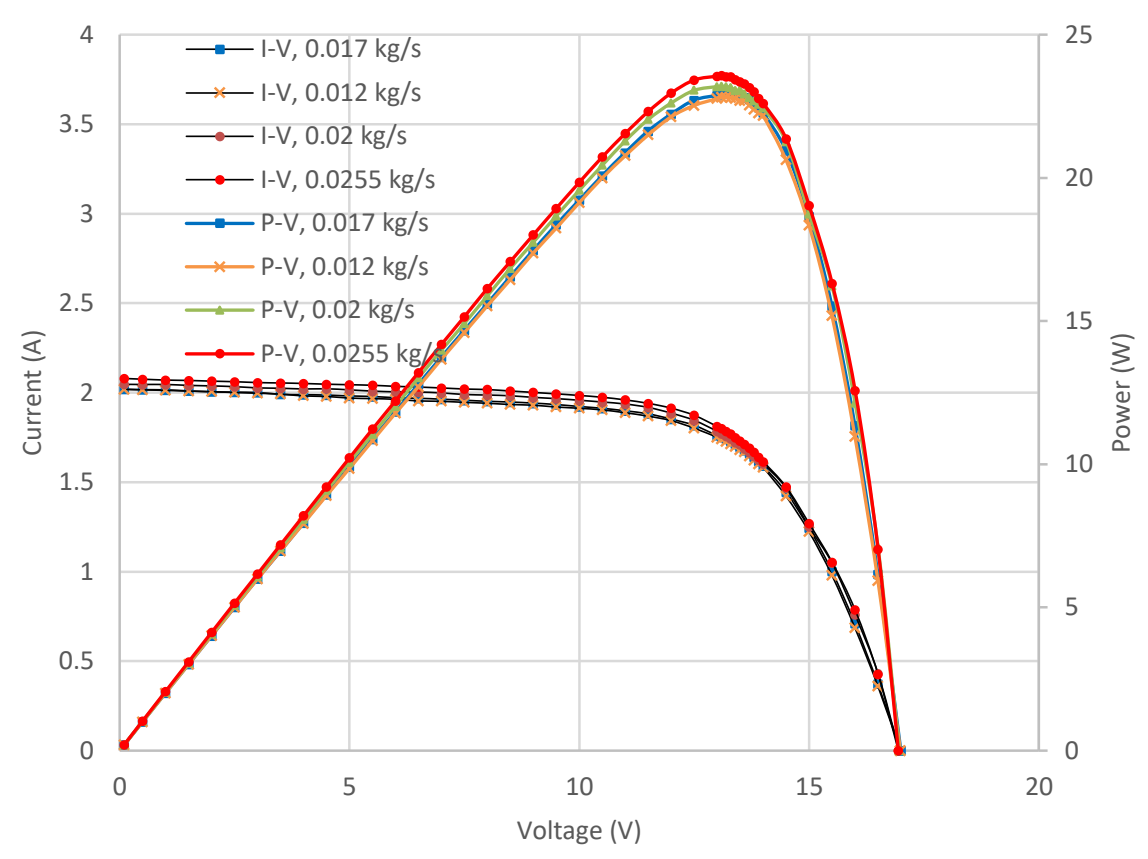

Fig. 6. Current (I) and power (P) over voltage (V) for the PV module with cooling at $900 \mathrm{~W} / \mathrm{m}^{2}$ intensity

Table 2

Effect of radiation intensity and mass flow rate on the $\mathrm{V}_{\mathrm{oc}}$ and $\mathrm{I}_{\mathrm{sc}}$ of the PV/T water collector

\begin{tabular}{lllllll}
\hline $\mathrm{S}\left(\mathrm{W} / \mathrm{m}^{2}\right)$ & $\dot{\mathrm{m}}(\mathrm{kg} / \mathrm{s})$ & $\mathrm{I}_{\mathrm{sc}}(\mathrm{A})$ & $\mathrm{V}_{\text {oc }}(\mathrm{V})$ & $\mathrm{P}_{\text {maks }}(\mathrm{W})$ & $\mathrm{FF}$ & $\eta_{e l}(\%)$ \\
\hline \multirow{3}{*}{500} & 0.012 & 0.841 & 17.52 & 9.853 & 0.669 & 3.17 \\
& 0.017 & 0.866 & 17.45 & 10.089 & 0.668 & 3.25 \\
& 0.02 & 0.870 & 17.38 & 10.159 & 0.672 & 3.27 \\
& 0.0255 & 0.878 & 17.33 & 10.336 & 0.679 & 3.33 \\
700 & 0.012 & 1.360 & 17.35 & 16.029 & 0.679 & 3.53 \\
& 0.017 & 1.376 & 17.26 & 16.079 & 0.677 & 3.54 \\
& 0.02 & 1.380 & 17.14 & 16.333 & 0.691 & 3.59 \\
& 0.0255 & 1.424 & 17.05 & 16.728 & 0.689 & 3.68 \\
900 & 0.012 & 2.018 & 17.00 & 22.823 & 0.665 & 3.88 \\
& 0.017 & 2.020 & 16.99 & 22.996 & 0.670 & 3.91 \\
& 0.02 & 2.046 & 16.90 & 23.200 & 0.671 & 3.95 \\
& 0.0255 & 2.080 & 16.84 & 23.580 & 0.673 & 4.01 \\
\hline
\end{tabular}

The effect of radiation intensity on $\mathrm{V}_{\mathrm{oc}}$ and $\mathrm{I}_{\mathrm{sc}}$ can be observed when radiation intensity increased from $500 \mathrm{~W} / \mathrm{m}^{2}$ to $900 \mathrm{~W} / \mathrm{m}^{2} ; \mathrm{l}_{\mathrm{sc}}$ increased from $0.878 \mathrm{~A}$ to $2.08 \mathrm{~A}$ with the mass of water content set at $0.0255 \mathrm{~kg} / \mathrm{s}$. $V_{\text {oc }}$ decreased with the increase in radiation intensity; at $500 \mathrm{~W} / \mathrm{m}^{2}$ intensity, $\mathrm{V}_{\text {oc }}$ was $17.33 \mathrm{~V}$, whereas at $900 \mathrm{~W} / \mathrm{m}^{2}, \mathrm{~V}_{\text {oc }}$ was $16.84 \mathrm{~V}$. $\mathrm{P}_{\mathrm{m}}$ increased with the increase in radiation intensity from $10.34 \mathrm{~W}$ to $23.58 \mathrm{~W}$. Electrical efficiency also increased when radiation intensity increased. The PV module efficiency ranged from $3.33 \%$ to $4.01 \%$, whereas the efficiency of the PV module without cooling ranged from $3.08 \%$ to $3.69 \%$. The FF experienced a slump from 0.679 to 0.673 when radiation intensity increased. Meanwhile, the FF value was reduced due to the increase in series resistance value $R_{s}$ when radiation intensity increased.

The effect of mass flow rate change on the PV/T water collector is shown in Table 3. At a mass flow rate of $0.012 \mathrm{~kg} / \mathrm{s}$, radiation intensity changed from $500 \mathrm{~W} / \mathrm{m}^{2}$ to $900 \mathrm{~W} / \mathrm{m}^{2}, \mathrm{I}_{\mathrm{sc}}$ increased from $0.841 \mathrm{~A}$ to $2.018 \mathrm{~A}$ and $\mathrm{V}_{\text {oc }}$ decreased from $17.52 \mathrm{~V}$ to $17.00 \mathrm{~V}$. The resulting power also increased from $9.853 \mathrm{~W}$ to $22.823 \mathrm{~W}$ under the same range of radiation intensity. The increase in $\mathrm{I}_{\mathrm{sc}}$ and the 
decrease in $V_{\text {oc }}$ were recorded when the mass flow rate was changed to $0.0255 \mathrm{~kg} / \mathrm{s}$, whereas the maximum power was recorded at $5.04 \%, 4.36 \%$ and $3.32 \%$ at 500,700 and $900 \mathrm{~W} / \mathrm{m}^{2}$, respectively, under the same mass flow rate ranging from $0.012 \mathrm{~kg} / \mathrm{s}$ to $0.0255 \mathrm{~kg} / \mathrm{s}$.

Table 3

Effect of radiation intensity and mass flow rate on the $\mathrm{V}_{\mathrm{oc}}$ and $\mathrm{I}_{\mathrm{sc}}$ of the PV/T water collector

\begin{tabular}{lllllll}
\hline $\mathrm{S}\left(\mathrm{W} / \mathrm{m}^{2}\right)$ & \multicolumn{3}{c}{$\dot{\mathrm{m}}=0.012 \mathrm{~kg} / \mathrm{s}$} & \multicolumn{3}{c}{$=0.0255 \mathrm{~kg} / \mathrm{s}$} \\
& $\mathrm{I}_{\mathrm{sc}}(\mathrm{A})$ & $\mathrm{V}_{\mathrm{oc}}(\mathrm{V})$ & $\mathrm{P}_{\mathrm{m}}(\mathrm{W})$ & $\mathrm{I}_{\mathrm{sc}}(\mathrm{A})$ & $\mathrm{V}_{\mathrm{oc}}(\mathrm{V})$ & $\mathrm{P}_{\mathrm{m}}(\mathrm{W})$ \\
\hline 500 & 0.841 & 17.52 & 9.853 & 0.878 & 17.33 & 10.336 \\
700 & 1.360 & 17.35 & 16.029 & 1.424 & 17.05 & 16.728 \\
900 & 2.018 & 17.00 & 22.823 & 2.080 & 16.84 & 23.580 \\
\hline
\end{tabular}

\section{Conclusions}

Results lead the following conclusions.

i. The generated power increases with radiation intensity, and PV module efficiency is slightly higher than that of the PV module without the spiral absorber.

ii. The solar radiation and mass flow rate affect open circuit voltage, closed circuit current and maximum power.

iii. The range of electrical efficiency obtained from the PV module without spiral absorber and water is $3.08 \%-3.69 \%$. At the intensity of $900 \mathrm{~W} / \mathrm{m}^{2}$ and mass flow rate of 0.0255 $\mathrm{kg} / \mathrm{s}$, an increase in electrical efficiency compared to PV module using spiral absorber and water fluid is $8.67 \%$.

\section{Acknowledgement}

The authors would like to thank Universiti Kebangsaan Malaysia (UKM) for funding (FRGS/1/2014/ST02/UKM/03/1) and (GGP-2017-045), Prof. Dr. Zahari Ibrahim for the indoor testing in the Physics Laboratory (Solar Simulator Lab) and the Solar Energy Research Institute, UKM.

\section{References}

[1] Fudholi, Ahmad, and Kamaruzzaman Sopian. "Review on exergy and energy analysis of solar air heater." International Journal of Power Electronics and Drive Systems 9, no. 1 (2018): 420.

https://doi.org/10.11591/ijpeds.v9.i1.pp420-426

[2] Fudholi, Ahmad, and Kamaruzzaman Sopian. "Review on solar collector for agricultural produce." International Journal of Power Electronics and Drive Systems 9, no. 1 (2018): 414.

https://doi.org/10.11591/ijpeds.v9.i1.pp414-419

[3] Fudholi, Ahmad, Lim Chin Haw, Kamaruzzaman Sopian, and Ahmed Mohamed Omer Abdulmula. "Primary study of tracking photovoltaic system for mobile station in Malaysia." International Journal of Power Electronics and Drive Systems 9, no. 1 (2018): 427.

https://doi.org/10.11591/ijpeds.v9.i1.pp427-432

[4] Fudholi, Ahmad, B. Bakhtyar, Habibis Saleh, Mohd Hafidz Ruslan, Mohd Yusof Othman, and Kamaruzzaman Sopian. "Drying of salted silver jewfish in a hybrid solar drying system and under open sun: Modeling and performance analyses." International journal of green energy 13, no. 11 (2016): 1135-1144.

https://doi.org/10.1080/15435075.2016.1175347

[5] Yahya, M., Ahmad Fudholi, and Kamaruzzaman Sopian. "Energy and exergy analyses of solar-assisted fluidized bed drying integrated with biomass furnace." Renewable Energy 105 (2017): 22-29.

https://doi.org/10.1016/i.renene.2016.12.049

[6] Fudholi, Ahmad, Muhammad Zohri, Nurul Shahirah Binti Rukman, Nurul Syakirah Nazri, Muslizainun Mustapha, Chan Hoy Yen, Masita Mohammad, and Kamaruzzaman Sopian. "Exergy and sustainability index of photovoltaic thermal (PVT) air collector: A theoretical and experimental study." Renewable and Sustainable Energy Reviews 100 (2019): 44-51.

https://doi.org/10.1016/i.rser.2018.10.019 
[7] Sopian, Kamaruzzaman, Ali HA Alwaeli, Husam Abdulrasool Hasan, and Ali Najah Al-Shamani. "Advances in high efficiency photovoltaic thermal solar collectors." Journal of Advanced Research in Fluid Mechanics and Thermal Sciences 47, no. 1 (2018): 1-7.

[8] Abdullah, Ahmed L., S. Misha, N. Tamaldin, M. A. M. Rosli, and F. A. Sachit. "Photovoltaic thermal/solar (PVT) collector (PVT) system based on fluid absorber design: A review." Journal of Advanced Research in Fluid Mechanics and Thermal Sciences 48, no. 2 (2018): 196-208.

[9] Singh, Baljit Singh Sarban, Chan Hoy Yen, Saleem Hussain Zaidi, and Kamaruzzaman Sopian. "Part II: enhanced performance of concentrating photovoltaic-thermal air collector with fresnel lens and compound parabolic concentrator (CPC)." Journal of Advanced Research in Fluid Mechanics and Thermal Sciences 47, no. 1 (2018): 1624.

[10] Rahman, M. M. "Energy Co-Generation in Photovoltaic Thermal-Collector (PVT) System: A Significant Increase in Efficiency." Journal of Advanced Research in Fluid Mechanics and Thermal Sciences 21, no. 1 (2016): 13-20.

[11] Zohri, Muhammad, Nurato Nurato, and Ahmad Fudholi. "Photovoltaic thermal (PVT) system with and without fins collector: theoretical approach." International Journal of Power Electronics and Drive Systems 8, no. 4 (2017): 1756. https://doi.org/10.11591/ijpeds.v8.i4.pp1756-1763

[12] Zohri, Muhammad, Lalu Darmawan Bakti, and Ahmad Fudholi. "Exergy assessment of photovoltaic thermal with vgroove collector using theoretical study." Telkomnika 16, no. 2 (2018): 550-557.

https://doi.org/10.12928/telkomnika.v16i2.8433

[13] Nazri, Nurul Syakirah, Ahmad Fudholi, Bardia Bakhtyar, Chan Hoy Yen, Adnan Ibrahim, Mohd Hafidz Ruslan, Sohif Mat, and Kamaruzzaman Sopian. "Energy economic analysis of photovoltaic-thermal-thermoelectric (PVT-TE) air collectors." Renewable and Sustainable Energy Reviews 92 (2018): 187-197.

https://doi.org/10.1016/i.rser.2018.04.061

[14] Nazri, Nurul Syakirah, Ahmad Fudholi, Mohd Hafidz Ruslan, and Kamaruzzaman Sopian. "Mathematical modeling of photovoltaic thermal-thermoelectric (PVT-TE) air collector." International Journal of Power Electronics and Drive Systems 9, no. 2 (2018): 795. https://doi.org/10.11591/ijpeds.v9.i2.pp795-802

[15] Fudholi, Ahmad, Muhammad Zohri, Goh Li Jin, Adnan Ibrahim, Chan Hoy Yen, Mohd Yusof Othman, Mohd Hafidz Ruslan, and Kamaruzzaman Sopian. "Energy and exergy analyses of photovoltaic thermal collector with $\nabla$ groove." Solar Energy 159 (2018): 742-750.

https://doi.org/10.1016/j.solener.2017.11.056

[16] Fudholi, Ahmad, and Kamaruzzaman Sopian. "R\&D of Photovoltaic Thermal (PVT) Systems: an overview." International Journal of Power Electronics and Drive Systems 9, no. 2 (2018): 803. https://doi.org/10.11591/ijpeds.v9.i2.pp803-810

[17] Kern Jr, E. C., and M. C. Russell. Combined photovoltaic and thermal hybrid collector systems. No. COO-4577-3; CONF-780619-24. Massachusetts Inst. of Tech., Lexington (USA). Lincoln Lab., 1978.

[18] Bahaidarah, H., Abdul Subhan, P. Gandhidasan, and S. Rehman. "Performance evaluation of a PV (photovoltaic) module by back surface water cooling for hot climatic conditions." Energy 59 (2013): 445-453.

https://doi.org/10.1016/i.energy.2013.07.050

[19] Raghuraman, Pattabiraman. "Analytical predictions of liquid and air photovoltaic/thermal, flat-plate collector performance." (1981): 291-298. https://doi.org/10.1115/1.3266256

[20] Chow, Tin Tai, Gang Pei, K. F. Fong, Z. Lin, A. L. S. Chan, and J. Ji. "Energy and exergy analysis of photovoltaicthermal collector with and without glass cover." Applied Energy 86, no. 3 (2009): 310-316. https://doi.org/10.1016/j.apenergy.2008.04.016

[21] Ibrahim, Adnan, Ahmad Fudholi, Kamaruzzaman Sopian, Mohd Yusof Othman, and Mohd Hafidz Ruslan. "Efficiencies and improvement potential of building integrated photovoltaic thermal (BIPVT) system." Energy Conversion and Management 77 (2014): 527-534. https://doi.org/10.1016/i.enconman.2013.10.033

[22] Aisyah, Cheku Nurul, Ahmad Fudholi, Mohd Yusof Othman, Adnan Ibrahim, Mohd Hafidz Ruslan, and Kamaruzzaman Sopian. "Kecekapan pengumpul PV/T menggunakan pengumpul terma reka bentuk pilin." Sains Malaysiana 47, no. 4 (2018): 853-859. https://doi.org/10.17576/ism-2018-4704-25

[23] Fudholi, Ahmad, Kamaruzzaman Sopian, Mohammad H. Yazdi, Mohd Hafidz Ruslan, Adnan Ibrahim, and Hussein A. Kazem. "Performance analysis of photovoltaic thermal (PVT) water collectors." Energy conversion and management 78 (2014): 641-651.

https://doi.org/10.1016/i.enconman.2013.11.017 